\title{
EFEKTIVITAS MIRROR THERAPY EXERCISE TERHADAP KEMAMPUAN FUNGSIONAL WAJAH PENDERITA FACIAL PALSY: STUDI LITERATUR
}

\author{
Widya Munawwarah $^{1^{*}}$, Nia Kurniawati ${ }^{2}$, Dwi Agustina ${ }^{3}$ \\ 1,2,3Program Studi Sarjana Terapan Fisioterapi Poltekkes Kemenkes Jakarta III \\ Jl. Arteri JORR Jatiwarna Kec. Pondok Melati 17415. Kota Bekasi - Jawa Barat \\ *Email korespondesi: munawwarahdy@gmail.com
}

\begin{abstract}
ABSTRAK
Latar Belakang: Facial palsy adalah suatu kondisi neurologis yang memengaruhi fungsi motorik wajah ditandai dengan asimetri dan kelemahan otot sebagian atau seluruh wajah sehingga menurunkan kemampuan fungsional wajah. Mirror therapy exercise merupakan suatu latihan berupa senam wajah dengan meggunakan cermin atau software untuk menghasilkan umpan balik visual dari bagian tubuh yang terkena lesi dan menghasilkan gerakan di sisi tubuh yang terkena. Tujuan: Untuk mengetahui efektivitas mirror therapy exercise terhadap kemampuan fungsional wajah penderita facial palsy melalui kajian literatur. Metode Penelitian: Jenis penelitian ini deskriptif dengan desain studi literatur. Literatur 10 tahun terakhir dikumpulkan dari 16 search engine dengan menggunakan teknik PICOS. Selanjutnya diseleksi awal dan metodologi, lalu dimasukan ke aplikasi Mendeley untuk literatur terduplikasi. Literatur yang eligible diekstraksi dengan filterisasi metode CONSORT. Hasil: Berdasarkan7 literatur yang eligible, mirror therapy exercise dengan kombinasi ataupun modifikasi efektif dalam meningkatkan kemampuan fungsional wajah penderita facial palsy. Kesimpulan: Mirror therapy exercise memiliki efektivitas yang lebih signifikan dibandingkan dengan intervensi lain dalam meningkatkan kemampuan fungsional wajah penderita facial palsy jika mirror therapy exercise yang menggunakan cermin maupun tablet PC dilakukan dengan kombinasi intervensi lainnya seperti electrical stimulation (ES), latihan orofasial, dan mirror imagery dengan perangkat lunak.
\end{abstract}

Kata Kunci: facial palsy; mirror therapy exercise; kemampuan fungsional wajah.

\begin{abstract}
Background: Facial palsy is a neurological condition that affects facial motor function characterized by asymmetry and muscle weakness in part or all of the face, thereby reducing facial functional abilities. Mirror therapy exercise is an exercise in the form of facial exercises using a mirror or software to generate visual feedback from the affected body part and produce movement on the affected side of the body. Objective: To determine the effectiveness of mirror therapy exercise on the facial functional abilities of patients with facial palsy through a literature review. Methods: This type of research is descriptive with a literature study design. The literature of the last 10 years was collected from 16 search engines using the PICOS technique. Furthermore, the initial selection and methodology, then entered into the Mendeley application for duplicated literature. Eligible literature was extracted by filtering the CONSORT method. Results: Based on 7 eligible literatures, mirror therapy exercise with combinations or modifications is effective in improving facial functional abilities of patients with facial palsy. Conclusion: Mirror therapy exercise has a more significant effectiveness compared to other interventions in improving facial functional abilities of patients with facial palsy if mirror therapy exercise using mirrors or tablet PCs is carried out with a combination of other interventions such as electrical stimulation (ES), orofacial exercises, and mirror imagery with software.
\end{abstract}

Keywords: facial palsy; mirror therapy exercise; facial function 


\section{PENDAHULUAN}

Facial palsy adalah suatu kondisi neurologis yang memengaruhi fungsi motorik wajah, terdiri dari central facial palsy dan peripheral facial palsy. Central facial palsy terjadi akibat kerusakan segmen sentral saraf yaitu lesi pada upper motor neuron (UMN) sedangkan peripheral facial palsy terjadi akibat kerusakan perifer saraf yaitu lesi pada lower motor neuron (LMN) (Bharathi et al., 2019; Vaughan et al., 2020).

Central facial palsy adalah gejala awal yang umumnya terjadi pada pasien pasca stroke dan cedera neurologis lainnya. Peripheral facial palsy yang belum diketahui penyebabnya (idiopatik) disebut Bell's palsy, merupakan penyebab paling umum yaitu sekitar $75 \%$ dari facial palsy (Vaughan et al., 2020; Hassan et al., 2020).

Pada mayoritas studi dengan populasi yang besar mengungkapkan kejadian facial palsy sebesar 15-30 kasus per 100.000 orang/tahun. Insiden di Amerika Serikat kurang lebih 23 kasus dan di Inggris 20 kasus per 100.000 orang/tahun. Sulit untuk menemukan data epidemiologi mengenai facial palsy di Indonesia, namun data terakhir yang tersedia dari penelitian sebelumnya menunjukan frekuensi terjadinya Bell's palsy di Indonesia sebesar $19,55 \%$, dari seluruh kasus neuropati (Rowhani-Rahbar et al., 2012; Moch, 2017).

Baru-baru ini sebuah penelitian menyebutkan bahwa prevalensi facial palsy adalah $21 \%$ lebih tinggi di Italia pada tahun 2020 dibandingkan dengan kejadian pada tahun 2019 selama pandemic COVID-19. Peripheral facial palsy terdeteksi sebagai temuan awal pada 5 dari 8 pasien yang terdeteksi positif COVID-19. Agen COVID-19, virus SARSCoV-2, dapat berdampak pada fungsi saraf wajah dengan efek toksik langsung ke saraf atau dengan meningkatkan hiperkoagulopati. Peripheral facial palsy dapat terlihat selama infeksi COVID-19 dan terkadang muncul hingga satu bulan setelah diagnosis. (Codeluppi et al., 2020; Egilmez, 2021; Oke et al., 2021)

Berdasarkan data tingkat Bell's palsy pada pasien dengan diagnosis COVID-19 dari 41 organisasi layanan kesehatan di seluruh dunia selama rentang 1 tahun, Dari 348.088 pasien yang diidentifikasi dengan COVID19, 284 memiliki diagnosis Bell's palsy dalam waktu 8 minggu setelah diagnosis COVID-19; 153 pasien memiliki Bell's palsy baru, sedangkan 131 memiliki Bell's palsy berulang. Ini menunjukkan bahwa COVID-19 dapat menjadi faktor risiko facial palsy (Akina Tamaki et al., 2021).

Central facial palsy menyebabkan defisit fungsional pada wajah yang memengaruhi ekspresi wajah dan dapat ditandai dengan asimetri wajah dan kelemahan hanya pada bagian bawah wajah seperti sudut mulut terkulai, berkurangnya kekuatan dan efisiensi pengunyahan, senyum asimetris dan disartria, sedangkan peripheral facial palsy dapat memengaruhi bagian bawah wajah dan dahi seperti sudut mulut terkulai, garis dahi menghilang, lipatan palpebra melebar, dan lid margin mata tidak tertutup, kantung mata bawah dan punctum jatuh, disertai air mata yang menetes tanpa disadari. Pada penderita facial palsy fungsi saraf wajah terganggu sehingga dapat menyebabkan gangguan aktivitas sehari-hari (Vaughan et al., 2020; Adam, 2019; Chang et al., 2016).

Dalam penelitian sebelumnya, facial palsy berdampak signifikan pada peningkatan stress dalam psikologis seseorang yang masalah kecemasan, depresi, dan penurunan tingkat kepercayaan diri akibat dari gangguan kemampuan fungsional wajah untuk mengekspresikan emosi, yang merupakan aspek penting dari komunikasi tatap muka. (Jason C. Nellis et al., 2017)

Untuk mengatasi gangguan kemampuan fungsional wajah pada facial palsy maka fisioterapi memiliki peranan yang sangat penting. Fisioterapi dapat melakukan rehabilitasi non-surgical/nonfarmakologi seperti infrared, massage, electrical stimulation, Proprioceptive Neuro Muscular Facilitation Technique, namun salah satu penanganan fisioterapi yang dapat dilakukan dirumah secara mandiri adalah mirror therapy exercise.

Menurut Bukhari et al., 2020, mirror therapy exercise adalah metode rehabilitasi 
neuromuskular wajah yang menggunakan umpan balik visual untuk meningkatkan gerakan fungsional, simetri, dan memperbaiki aktivitas otot yang tidak teratur. Umpan balik visual datang dari bagian wajah yang berlawanan yang menghasilkan gerakan di sisi wajah yang terkena.

Ding et al., 2020 dalam penelitiannya menyebutkan bahwa mirror therapy exercise dapat meningkatkan fungsi wajah dan memperpendek durasi pengobatan. Sejalan dengan Abidin, and Haryanto, 2017, hasil penelitian menunjukan bahwa penggunaan infra red, massage dan mirror therapy exercise efektif dalam meningkatkan kekuatan otot serta perbaikan saraf wajah.

Mirror therapy exercise didasarkan pada kontrol stimulus-respons hipotesis dan memungkinkan pasien untuk secara visual mengapresiasi kembalinya aktivitas otot. Dengan melihat wajah yang tidak terpengaruh melakukan latihan secara normal, peningkatan aktivitas jalur komando motorik dari wilayah yang tidak terpengaruh digunakan untuk melengkapi wilayah yang rusak. Penguatan psikologis dari melihat wajah normal memberi pasien motivasi tambahan untuk melakukan latihan. Teknik baru ini merupakan bentuk biofeedback yang telah digunakan dalam sejumlah penelitian berbeda. (Barth et al., 2020)

Berdasarkan uraian tersebut maka peneliti tertarik untuk mengidentifikasi bukti terkini dari berbagai literatur mengenai efektivitas mirror therapy exercises terhadap kemampuan fungsional wajah penderita facial palsy. Diharapkan hasil penelitian ini dapat bermanfaat dalam meningkatkan mutu pelayanan fisioterapi.

\section{METODE PENELITIAN}

Penelitian ini menggunakan jenis penelitian deskriptif dengan desain studi literatur dengan hasil penelitian menggunakan literatur sebagai sumber data. Metode pengumpulan data dilakukan dengan mengunduh literatur pada 16 search engine yaitu: PubMed, Semantic Scholar, Science Direct, Proquest, Oxford Academic, SAGE Journal, Springer Link, LANCET Journal, JTSOR, BMC, ERUDIT Journal, HIGHWIRE,
MDPI, Taylor \& Francis, Elsevier Journal, dan PMC.

Waktu pencarian literatur dilakukan pada tanggal 26-27 mei 2021 dan 06-07 juni 2021, sedangkan pengolahan data dilakukan pada tanggal 10 Juni-21 Juni 2021. Populasi yang diambil pada penelitian ini adalah semua literatur yang relevan dengan perlakuan yaitu mirror therapy exercise dan outcome kemampuan fungsional wajah pada penderita facial palsy.

Peneliti melakukan pencarian literatur pada 16 search engine yang berbeda menggunakan kata kunci yang ditetapkan berdasarkan pendekatan PICOS yaitu P (Person) yaitu Facial Palsy, I (Intervention) yaitu Mirror Therapy Exercise, C (Comparison) tidak ditentukan, kemudian O (Outcome) yaitu Kemampuan Fungsional Wajah dan S (Studies) yaitu Clinical Trial/Eksperimental atau Randomized Controlled Trial.

Hasil pencarian literatur yang didapat berdasarkan kata kunci kemudian diseleksi dengan instrument seleksi awal berdasarkan kriteria inklusi dan eksklusi. Kriteria inklusi penelitian ini mencakup PICOS sedangkan kriteria eksklusi penelitian ini adalah literatur yang berbayar, literatur tidak berbahasa inggris dan indonesia, literatur terbitan lebih dari 10 tahun terakhir.

Literatur yang didapatkan kemudian dilakukan seleksi metodologi dan pengecekan duplikasi dengan menggunakan aplikasi Mendeley. Selanjutnya dilakukan pengolahan data dengan tabel ekstraksi yang mengadopsi secara global proses filterisasi metode CONSORT yang meliputi judul, nama jurnal, tahun terbit, desain penelitian, subjek/sampel, perlakuan pada kelompok intervensi dan kelompok pembanding (jika ada), outcome dan cara ukurnya serta analisis univariat dan bivariat dengan hasilnya. 


\section{HASIL PENELITIAN}

Proses penyeleksian literatur dapat dilihat pada diagram PRISMA berikut ini.

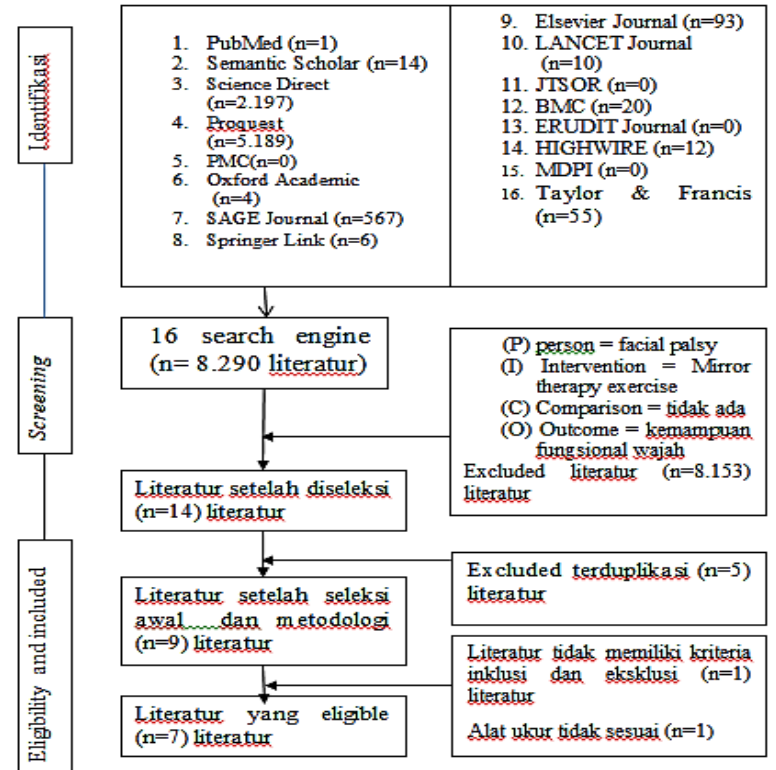

Gambar 1. Diagram Alur Proses Penyeleksian Literatur

Setelah melakukan pencarian menggunakan filter pada 16 search engine didapatkan 8.290 literatur. Lalu dilakukan seleksi awal ditemukan sebanyak 8.153 literatur excluded sehingga tersisa 14 literatur. Kemudian, dilakukan screening dengan memeriksa duplikasi artikel jurnal menggunakan aplikasi Mendeley. Didapatkan 5 literatur excluded karena terduplikasi. Lalu pada seleksi metodologi terdapat 2 jurnal yang gugur sehingga menghasilkan 7 literatur terbitan 5 tahun terakhir yang memenuhi kriteria (eligible) untuk kemudian diekstraksi pada distribusi literatur (tabel 1) dan karakteristik literatur (tabel 2).

Tabel 1. Distribusi Literatur

\begin{tabular}{cccc}
\hline No & Uraian & $\begin{array}{c}\text { Ju } \\
\text { ml } \\
\text { ah }\end{array}$ & Persentase \\
\hline 1. & \multicolumn{3}{c}{ Tahun Publikasi } \\
\hline & 2017 & 2 & $28,6 \%$ \\
& 2019 & 1 & $14,3 \%$ \\
& 2020 & 4 & $57,1 \%$ \\
\hline $\mathbf{2 .}$ & 10 & Besar Sampel \\
& 20 & 1 & $14,3 \%$ \\
& 28 & 1 & $14,3 \%$ \\
& 25 & 1 & $14,3 \%$ \\
& 30 & 1 & $14,3 \%$ \\
& 22 & 1 & $14,3 \%$ \\
\hline
\end{tabular}

\begin{tabular}{|c|c|c|c|}
\hline & 21 & 1 & $14,3 \%$ \\
\hline 3. & \multicolumn{3}{|c|}{$\begin{array}{r}\text { Intervensi } \\
\end{array}$} \\
\hline & $\begin{array}{l}\text { Mirror } \\
\text { therapy } \\
\text { exercise and } \\
\text { motor } \\
\text { imagery }\end{array}$ & 1 & $14,3 \%$ \\
\hline & $\begin{array}{l}\text { Mirror effect } \\
\text { plus protocol } \\
(M E P P)\end{array}$ & 1 & $14,3 \%$ \\
\hline & Mirror book & 1 & $14,3 \%$ \\
\hline & $\begin{array}{l}\text { Mirror } \\
\text { therapy } \\
\text { exercise }\end{array}$ & 2 & $28,6 \%$ \\
\hline & $\begin{array}{l}\text { Tablet PC } \\
\text { mirror } \\
\text { application }\end{array}$ & 1 & $14,3 \%$ \\
\hline 4. & \multicolumn{3}{|c|}{ Pembanding } \\
\hline & $\begin{array}{l}\text { Strengthenin } \\
\text { g exercise }\end{array}$ & 1 & $14,3 \%$ \\
\hline & Edukasi & 1 & $14,3 \%$ \\
\hline & $\begin{array}{l}\text { Biofeedback } \\
\text { set }\end{array}$ & 1 & $14,3 \%$ \\
\hline & $\begin{array}{l}\text { Terapi } \\
\text { konvensional }\end{array}$ & 4 & $57,1 \%$ \\
\hline 5. & \multicolumn{3}{|c|}{ Dosis Intervensi } \\
\hline & $\begin{array}{l}\text { Dosis } \\
\text { Latihan }\end{array}$ & & \\
\hline & $\begin{array}{l}\text { Setiap hari } \\
\text { selama } 2 \\
\text { minggu }\end{array}$ & 1 & $14,3 \%$ \\
\hline & $\begin{array}{l}20 \text { menit } \\
\text { dalam } 4 \\
\text { minggu } \\
\text { dengan } \\
\text { frekuensi } \\
3 \mathrm{x} / \text { minggu }\end{array}$ & 1 & $14,3 \%$ \\
\hline & $\begin{array}{l}4 \text { sesi selama } \\
2 \text { minggu }\end{array}$ & 1 & $14,3 \%$ \\
\hline & $\begin{array}{l}2-19 \text { sesi } \\
\text { untuk grup } \\
\text { intervensi, 2- } \\
22 \text { sesi untuk } \\
\text { grup kontrol }\end{array}$ & 1 & $14,3 \%$ \\
\hline & $\begin{array}{l}15 \text { menit } \\
\text { frekuensi } 2 x / \\
\text { sehari selama } \\
14 \text { hari }\end{array}$ & 1 & $14,3 \%$ \\
\hline & $\begin{array}{l}\text { Durasi } \\
\text { penelitian } \\
\text { selama } 3 \\
\text { bulan. Pada } \\
\text { bulan } \\
\text { pertama } 10\end{array}$ & 1 & $14,3 \%$ \\
\hline
\end{tabular}


Indonesian Journal of Physiotherapy

Vol. 1, No. 2, Agustus 2021

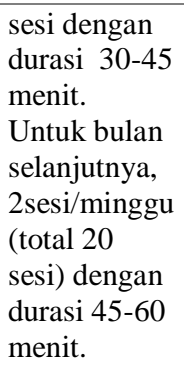

Kemampuan

Fungsional

Wajah $=$

\begin{tabular}{|c|c|}
\hline \multirow{2}{*}{$\begin{aligned} \text { a. Housebrac } \\
\text { kmann } \\
\text { scale } \\
\text { b. Facial } \\
\text { disability } \\
\text { Index }\end{aligned}$} & 5 \\
\hline & 2 \\
\hline
\end{tabular}

Simteri

Wajah dan

Synkinesis=

Sunnybrook

facial

grading

system/

Facial nerve

garding

system (SFG

2.0)

Kualitas

Hidup=

SF-36

Facial

Clinimetric

Evaluation

(FaCE) scale a. Univariat

Mean

$71,4 \%$

Median

$28,6 \%$

b. Bivariat

Mann-

$28,6 \%$

Whitney $U$

test

Independent $28,6 \%$

t test

The paired $114,3 \%$

sample t-test

Mann

$1 \quad 14,3 \%$

Whitney and

Hodges-

Lehman 
Tabel 2. Karakteristik Literatur

\begin{tabular}{|c|c|c|c|c|c|}
\hline No & $\begin{array}{c}\text { Penulis/Judul/ } \\
\text { Jurnal/Tahun/ } \\
\text { Desain Studi }\end{array}$ & Partisipan & Perlakuan & Cara Ukur & Hasil \\
\hline 1. & $\begin{array}{l}\text { (Bharathi et al., } \\
\text { 2019)/ The } \\
\text { Efficiacy Of } \\
\text { Mirror therapy } \\
\text { exercise in } \\
\text { Facial Palsy } \\
\text { among Subject } \\
\text { with Facial } \\
\text { Paralysis/ } \\
\text { International } \\
\text { Journal of } \\
\text { Research and } \\
\text { Scientific } \\
\text { Innovation } \\
\text { (IJRSI)/ 2019/ } \\
\text { RCT }\end{array}$ & $\begin{array}{l}\mathrm{n}=10 \text { orang } \\
\text { Inklusi : } \\
\text { Subjek dengan lesi } \\
\text { Upper Motor Neuron } \\
(\text { UMN), MMSE > 25, } \\
\text { usia 21-50th } \\
\text { Eksklusi : } \\
\text { Subjek dengan lesi } \\
\text { Lower Motor Neuron } \\
\text { (LMN), kanker mulut, } \\
\text { Fraktur sendi } \\
\text { temporomandibular, } \\
\text { Implantasi gigi baru- } \\
\text { baru ini, Cedera kepala }\end{array}$ & $\begin{array}{l}\text { Grup A }(\mathrm{n}=5) \text { : } \\
\text { Electrical } \\
\text { Stimulation } \\
\text { durasi } 15 \text { sampai } \\
20 \text { menit } \\
\text { Grup B }(\mathrm{n}=5) \text { : } \\
\text { Electrical } \\
\text { stimulation } \\
\text { durasi } 15 \text { sampai } \\
20 \text { menit dan } \\
\text { mirror therapy } \\
\text { exercise } \\
\text { Intervensi } \\
\text { dilakukan setiap } \\
\text { hari selama } 2 \\
\text { minggu }\end{array}$ & $\begin{array}{l}\text { Facial } \\
\text { Disabilty } \\
\text { Index }\end{array}$ & $\begin{array}{l}\text { Univariat (mean) } \\
\text { Grup A : pre } 74.8 \text {, post } \\
\text { 91.3 } \\
\text { Grup B : pre } 66, \text { post } 105 \\
\text { Bivariat } \\
\text { - Perbedaan mean } \\
\quad \text { sebelum dan sesudah } \\
\text { pada grup A }(p= \\
\text { 0.013) } \\
\text { - Perbedaan mean } \\
\quad \text { sebelum dan sesudah } \\
\text { pada grup B }(p=0.008) \\
\text { - Uji T test }(\mathrm{t}=-2.479) \\
\text { Perbedaan signifikan antara } \\
\text { kedua grup }(p \text { value }= \\
0.038 \approx p \text { value }<0.05)\end{array}$ \\
\hline 2. & $\begin{array}{c}\text { (Eliyspoor C } \\
\text { Baghban et al., } \\
\text { 2017)/ The } \\
\text { Comparison } \\
\text { between } \\
\text { Exercise } \\
\text { Therapy and } \\
\text { Biofeedback } \\
\text { Therapy in } \\
\text { Facial } \\
\text { Function and } \\
\text { Quality Of Life } \\
\text { of Bell's palsy/ } \\
\text { Journal of } \\
\text { Clinical } \\
\text { Physiotherapy } \\
\text { Research } \\
\text { (JCPR)/ 2017/ } \\
\text { Clinical Trial }\end{array}$ & $\begin{array}{l}\mathrm{n}=20 \text { orang } \\
\text { Inklusi : } \\
\text { Subjek dengan } \\
\text { peripheral facial palsy } \\
\text { unilateral akut(bell's } \\
\text { palsy), menerima obat- } \\
\text { obatan (kortikosteroid } \\
\text { dan / atau anti virus) } \\
\text { selama 10-14 hari } \\
\text { Eksklusi : pasien } \\
\text { dengan facial palsy } \\
\text { sentral, kekambuhan } \\
\text { facial palsy, facial } \\
\text { palsy bilateral, } \\
\text { gangguan neurologis, } \\
\text { mental dan psikologis, } \\
\text { penyakit kulit dan } \\
\text { kontraindikasi } \\
\text { massage }\end{array}$ & $\begin{array}{l}\text { Grup A (n=10) : } \\
\text { Massage } 2 \\
\text { menit, dan } \\
\text { strengthening } \\
\text { exercise } \\
\text { (mengurangi alis } \\
\text { terangkat, sudut } \\
\text { bibir, cemberut, } \\
\text { mengerutkan } \\
\text { bibir) dengan } \\
\text { set biofeedback } \\
20 \text { menit } \\
\text { Grup B (n=10) : } \\
\text { Massage } 2 \\
\text { menit, dan } \\
\text { mirror therapy } \\
\text { exercise didepan } \\
\text { cermin selama } \\
20 \text { menit } \\
\text { (masing-masing } \\
5 \text { kali). } \\
\text { Intervensi } \\
\text { dilakuan selama } \\
4 \text { minggu } \\
\text { dengan frekuensi } \\
3 x / m i n g g u\end{array}$ & $\begin{array}{l}\text { House- } \\
\text { brackman } \\
n \text { and } \\
\text { SF-36 } \\
\text { questionn } \\
\text { aire }\end{array}$ & $\begin{array}{l}\text { Univariat (mean) } \\
\text { Hosebrackmann= } \\
\bullet \quad \text { Grup A } \\
\text { sebelum } 5 \pm 0.67 \\
\text { sesudah } 2.5 \pm 0.7 \\
\text { - Grup B } \\
\text { sebelum } 5.5 \pm 0.53 \\
\text { setelah } 2.9 \pm 0.74 \\
\text { Bivariat } \\
\text { - Perbedaan mean } \\
\quad \text { sebelum dan sesudah } \\
\text { pada grup A ( } p= \\
\text { 0,004) } \\
\text { - Perbedaan mean } \\
\text { sebelum dan sesudah } \\
\text { pada grup B ( } p=0,004 \text { ) } \\
\text { Independent T test } \\
\text { facial function (p= } \\
\text { 0.85) } \\
\text { QoL (p=0.07) } \\
\text { Maka hasil pada fungsi } \\
\text { wajah maupun QoL tidak } \\
\text { signifikan dengan } p \\
\text { value }>0.05\end{array}$ \\
\hline 3. & $\begin{array}{l}\text { (Martineau et } \\
\text { al., 2020)/ The } \\
\text { Mirror Effect } \\
\text { Plus Protocol } \\
\text { for acute Bell's } \\
\text { palsy: a } \\
\text { randomised } \\
\text { and } \\
\text { longitudinal } \\
\text { study on facial } \\
\text { rehabilitation/ }\end{array}$ & $\begin{array}{l}\mathrm{n}=28 \text { orang } \\
\text { Inklusi } \\
\text { Subjek dengan } \\
\text { peripheral facial palsy } \\
\text { unilateral akut(bell's } \\
\text { palsy), } \\
\text { Bell's Palsy berat dan } \\
\text { total menggunakan } \\
\text { obat, } \\
\text { status kognitif normal. }\end{array}$ & $\begin{array}{l}\text { Grup A }(\mathrm{n}=15) \text { : } \\
\text { Edukasi } \\
\text { konseling dasar, } \\
\text { dan tidak ada } \\
\text { sesi terapi. } \\
\text { Grup B }(\mathrm{n}=13) \text { : } \\
\text { Mirror Effect } \\
\text { Plus Protocol } \\
(\text { MEPP) yaitu } \\
\text { mirror therapy }\end{array}$ & $\begin{array}{l}\text { House- } \\
\text { Brackman } \\
\text { n } 2.0 \\
\text { score; dan } \\
\text { Sunnybro } \\
\text { ok Facial } \\
\text { Grading } \\
\text { System }\end{array}$ & $\begin{array}{l}\text { Univariat (median) } \\
-\quad \text { Grup A } \\
\text { House brackmann scale: } \\
\text { Grade IV : pre } 3 \\
\text { Grade V : pre } 4 \\
\text { Grade VI : pre } 3 \\
\text { Sunnybrook facial grading : } \\
26 \quad \text { Grup B } \\
\text { House brackmann scale: } \\
\text { Grade IV : pre } 3\end{array}$ \\
\hline
\end{tabular}




\begin{tabular}{|c|c|c|c|c|c|}
\hline & $\begin{array}{l}\text { Acta Oto- } \\
\text { Laryngologica } \\
\text { Journal/ } \\
\text { 2020/RCT }\end{array}$ & $\begin{array}{l}\text { Eksklusi : alasan } \\
\text { medis (Ramsay Hunt } \\
\text { Syndrome) }\end{array}$ & $\begin{array}{l}\text { exercise dengan } \\
\text { bantuan halaman } \\
\text { web gratis } \\
\text { (www.webcamto } \\
\text { y.com) } \\
\text { Intervensi } \\
\text { dilakukan } 4 \text { sesi } \\
\text { dalam } 2 \text { minggu }\end{array}$ & & $\begin{array}{l}\text { Grade V : pre } 6 \\
\text { Grade VI : pre } 1 \\
\text { Sunnybrook facial grading : } \\
28 \\
\text { Bivariat } \\
\text { Mann Whitney and Hodges- } \\
\text { Lehman test }(p- \\
\text { value }=0.073) \\
\text { Perbedaan tidak signifikan } \\
\text { antara kedua grup }(p \\
\text { value }>0.05)\end{array}$ \\
\hline 4. & $\begin{array}{l}\text { (Barth et al., } \\
\text { 2020)/ Mirror } \\
\text { Book Therapy } \\
\text { for the } \\
\text { treatment of } \\
\text { Idiopathic } \\
\text { Facial Palsy/ } \\
\text { Ear, Nose and } \\
\text { Throat } \\
\text { Journal/ 2020/ } \\
\text { RCT }\end{array}$ & $\begin{array}{l}\mathrm{n}=25 \text { orang } \\
\text { Inklusi : pasien yang } \\
\text { dirawat karena facial } \\
\text { palsy antara tahun } \\
1997 \text { dan } 2008 \\
\text { Eksklusi : pasien } \\
\text { selain idiophatic facial } \\
\text { paralysis }\end{array}$ & $\begin{array}{l}\text { Grup A (n=15) } \\
\text { menerima } \\
\text { mirror book } \\
\text { therapy } \\
\text { dilakukan } \\
\text { selama 2-19 sesi } \\
\text { Grup B (n=10) } \\
\text { Grup kontrol (B) } \\
\text { menerima } \\
\text { perawatan } \\
\text { rehabilitasi } \\
\text { wajah standar } \\
\text { yang terdiri dari } \\
\text { edukasi ulang } \\
\text { neuromuskuler, } \\
\text { massage, } \\
\text { pelepasan } \\
\text { myofascial, } \\
\text { peregangan dan } \\
\text { pelatihan } \\
\text { postural selama } \\
\text { 2-22 sesi }\end{array}$ & $\begin{array}{l}\text { Sunnybro } \\
\text { ok Facial } \\
\text { Grading } \\
\text { System } \\
\text { (FGS) } \\
\text { Observati } \\
\text { onal Scale } \\
\text { dan } \\
\text { Facial } \\
\text { Disability } \\
\text { Index } \\
\text { (FDI) }\end{array}$ & 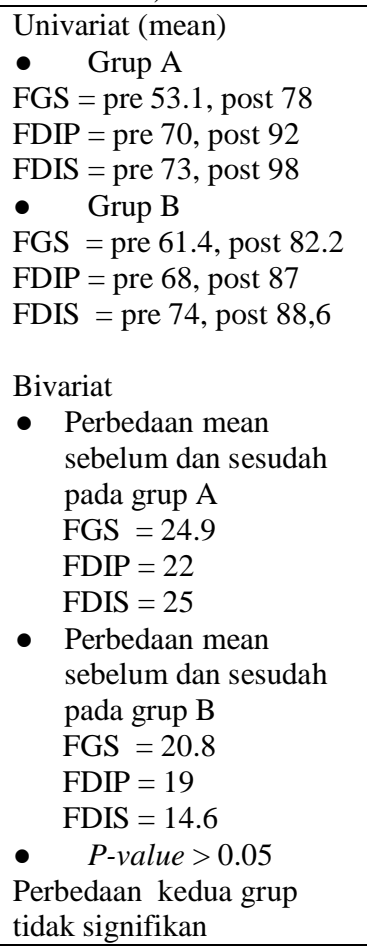 \\
\hline 5. & $\begin{array}{l}\text { (Bukhari et al., } \\
\text { 2020)/ Effects } \\
\text { of Mirror } \\
\text { therapy } \\
\text { exercise on } \\
\text { Bell's Palsy/ } \\
\text { Journal of } \\
\text { Riphah College } \\
\text { of } \\
\text { Rehabilitation } \\
\text { Sciences/ 2020/ } \\
\text { RCT }\end{array}$ & $\begin{array}{l}\mathrm{n}=30 \text { orang } \\
\text { Inklusi : } \\
\text { 1. grup usia antara 25- } \\
50 \text { tahun } \\
\text { 2. } \quad \text { kasus Bell's palsy } \\
\text { yang terdiagnosis } \\
\text { 3. } \begin{array}{l}\text { onset akut 1-3 } \\
\text { minggu dan saraf }\end{array} \\
\text { wajah } \\
\text { 4. House- } \\
\text { Brackmann kelas } \\
\text { III dan IV } \\
\text { Eksklusi : } \\
\text { 1. defisit neurologis } \\
\text { 2. defisit sensorik } \\
\text { gangguan kognitif }\end{array}$ & $\begin{array}{l}\text { Grup A ( } \mathrm{n}=15) \\
\text { mendapat terapi } \\
\text { electrical } \\
\text { stimulation dan } \\
\text { senam wajah } \\
\text { Grup B ( } \mathrm{n}=15) \\
\text { mendapat mirror } \\
\text { therapy exercise } \\
\text { dimana setelah } \\
\text { penerapan } \\
\text { electrical } \\
\text { stimulation } \\
\text { dilakukan } \\
\text { latihan di depan } \\
\text { cermin. Dua } \\
\text { belas sesi } \\
\text { intervensi } \\
\text { diberikan dalam } \\
\text { empat minggu } \\
\text { pada hari } \\
\text { alternatif. } \\
\text { Durasi penelitian } \\
\text { adalah } 6 \text { bulan. }\end{array}$ & $\begin{array}{l}\text { House- } \\
\text { Brackman } \\
\text { scale, dan } \\
\text { Sunnybro } \\
\text { ok facial } \\
\text { grading } \\
\text { system }\end{array}$ & $\begin{array}{l}\text { Univariat (mean) } \\
\text { House brackmann scale } \\
\bullet \quad \text { Grup A } \\
\text { sebelum } 28 \pm 15.203 \\
\text { sesudah } 50.33 \pm 13.746 \\
\bullet \quad \text { Grup B } \\
\text { sebelum } 36.40 \pm 17.574 \\
\text { setelah } 70.67 \pm 11.127 \\
\text { Bivariat } \\
\text { Paired sample t-test }(\mathrm{p} \\
\text { value }=0.00 \approx p \\
\text { value }<0.05)\end{array}$ \\
\hline
\end{tabular}




\begin{tabular}{|c|c|c|c|c|c|}
\hline 6. & $\begin{array}{l}\text { (Paolucci et al., } \\
\text { 2020)/ Give } \\
\text { me a kiss! an } \\
\text { integrative } \\
\text { rehabilitative } \\
\text { training } \\
\text { program with } \\
\text { motor imagery } \\
\text { and mirror } \\
\text { therapy } \\
\text { exercise for } \\
\text { recovery of } \\
\text { facial palsy/ } \\
\text { European } \\
\text { Journal of } \\
\text { physical and } \\
\text { rehabilitation } \\
\text { Medicine/2020/ } \\
\text { RCT }\end{array}$ & $\begin{array}{l}\mathrm{n}=22 \text { orang } \\
\text { Kriteria inklusi : } \\
\text { Facial palsy unilateral } \\
\text { setelah operasi untuk } \\
\text { neuroma akustik, } \\
\text { Kurang dari } 12 \text { bulan } \\
\text { setelah operasi, Usia } \\
18 \text { hingga } 60 \text { tahun, } \\
\text { House-brackmann n } \\
\text { scale (HBS) } \geq \text { III. } 21 \\
\text { kriteria eksklusi } \\
\text { adalah: wanita hamil, } \\
\text { adanya penyakit } \\
\text { autoimun atau } \\
\text { hematologi, kejiwaan, } \\
\text { tumor, dan diabetes. }\end{array}$ & $\begin{array}{l}\text { Grup A (n=11): } \\
\text { Mirror therapy } \\
\text { exercise } \\
\text { menggunakan } \\
\text { perangkat lunak } \\
\text { khusus berupa } \\
\text { mirror therapy } \\
\text { exercise and } \\
\text { motor imagery. } \\
\text { Grup B (n=11) : } \\
\text { pengobatan } \\
\text { rehabilitasi } \\
\text { tradisional } \\
\text { seperti massage; } \\
\text { latihan } \\
\text { pernapasan dan } \\
\text { relaksasi; latihan } \\
\text { huruf dan kata; } \\
\text { dan latihan } \\
\text { ekspresif. } \\
\text { Durasi penelitian } \\
\text { selama } 3 \text { bulan. } \\
\text { Pada bulan } \\
\text { pertama } 10 \text { sesi } \\
\text { dengan durasi } \\
\text { 30-45 menit. } \\
\text { Untuk bulan } \\
\text { selanjutnya, } \\
\text { 2sesi/minggu } \\
\text { (total } 20 \text { sesi) } \\
\text { dengan durasi } \\
\text { 45-60 menit. }\end{array}$ & $\begin{array}{l}\text { House- } \\
\text { brackman } \\
\text { scale } \\
\text { dan } \\
\text { facE scale }\end{array}$ & $\begin{array}{l}\text { Perbedaan median } \\
\text { sebelum dan sesudah } \\
\text { pada grup A } \\
\text { T0-T1 }: 1.5(0 ; 3) \\
\text { T1-T2 }: 1(0 ; 2) \\
\text { T2-T3 : } 0(0 ; 1) \\
\text { T3-FU : } 0(0 ; 0) \\
\text { T0-FU : } 2.5(2 ; 4) \\
\\
\text { Perbedaan median } \\
\text { sebelum dan sesudah } \\
\text { pada grup B } \\
\text { T0-T1 : } 1(0 ; 1) \\
\text { T1-T2 : } 0(0 ; 1) \\
\text { T2-T3 : } 1.5(0 ; 2) \\
\text { T3-FU : } 0(0 ; 0) \\
\text { T0-FU : } 2.5(1 ; 3) \\
\\
\text { Uji the Mann- } \\
\text { Whitney signifikan } \\
\text { (P=0,043) }\end{array}$ \\
\hline 7. & $\begin{array}{l}\text { (Kang et al., } \\
\text { 2017)/ Effects } \\
\text { of Mirror } \\
\text { therapy } \\
\text { exercise Using } \\
\text { a Tablet PC on } \\
\text { Central Facial } \\
\text { Paresis in } \\
\text { Stroke } \\
\text { Patients/ } \\
\text { Annals of } \\
\text { Rehabilitation } \\
\text { Medicine/ } \\
\text { 2017/ RCT }\end{array}$ & $\begin{array}{l}\mathrm{n}=21 \\
\text { Kriteria inklusi : } \\
\text { (1) facial palsy dengan } \\
\text { stroke hemisfer } \\
\text { unilateral pertama kali } \\
\text { (2) } 12 \text { minggu setelah } \\
\text { serangan stroke; dan } \\
\text { (3) Mampu mengikuti } \\
\text { perintah. } \\
\text { Kriteria eksklusi : } \\
\text { peripheral facial } \\
\text { palsy, mengalami } \\
\text { gangguan penglihatan, } \\
\text { memiliki riwayat } \\
\text { facial palsy tipe } \\
\text { sentral dan / atau tipe } \\
\text { perifer; sebelumnya, } \\
\text { kelumpuhan total sejak } \\
\text { onset stroke }\end{array}$ & $\begin{array}{l}\text { Grup A }(\mathrm{n}=10) \\
\text { Latihan orofasial } \\
\text { dan mirror } \\
\text { therapy exercise } \\
\text { menggunakan } \\
\text { tablet PC } \\
\text { selama } 15 \text { menit } \\
\text { dua kali sehari } \\
\text { selama } 14 \text { hari. } \\
\text { Grup B ( } \mathrm{n}=11) \\
\text { hanya menerima } \\
\text { edukasi tentang } \\
\text { latihan orofasial } \\
\text { dari terapis } \\
\text { wicara dan } \\
\text { bahasa. }\end{array}$ & $\begin{array}{l}\text { Regional } \\
\text { House- } \\
\text { Brackman } \\
\text { Grading } \\
\text { Scale }(R- \\
\text { HBGS) }\end{array}$ & $\begin{array}{l}\text { Univariat (mean) } \\
\text { Grup A } \\
\text { Mid-face }: \text { pre } 2,9 \pm 0,7 \text { post } \\
2,1 \pm 1,0 \\
\text { Mouth : pre } 3,3 \pm 1,6 \text { post } \\
2,3 \pm 1,6 \\
\text { Grup B } \\
\text { Mid-face }: \text { pre } 2,5 \pm 0,5 \text { post } \\
2,1 \pm 0,7 \\
\text { Mouth : pre } 3,5 \pm 1,1 \text { post } \\
2,8 \pm 1,3 \\
\text { Bivariat } \\
\text { - Perbedaan mean } \\
\quad \text { sebelum dan sesudah } \\
\quad \text { pada grup A } \\
\quad 1,45 \pm 0,90 \\
\text { Perbedaan mean } \\
\quad \text { sebelum dan sesudah } \\
\quad \text { pada grup B } \\
\quad 0,55 \pm 1,00 \\
\text { Mann- Whitney test } \\
\text { Perbedaan signifikan antara } \\
\text { kedua grup (p=0,04 } \approx p \\
\text { value }<0.05 \text { ) }\end{array}$ \\
\hline
\end{tabular}


Dari ketujuh literatur yang dikaji, pengukuran kemampuan fungsional wajah menggunakan dua alat ukur yaitu house brackman scale (5 literatur) dan Facial Disability Index (2 literatur). Hasil didapatkan bahwa mirror therapy exercise dapat meningkatkan kemampuan fungsional wajah penderita facial palsy dengan perbedaan nilai statistik antara sebelum dan setelah intervensi signifikan $(p$ value < 0.05) pada semua literatur.

Dibandingkan dengan intevensi lain, mirror therapy exercise berupa latihan wajah/senam wajah di depan cermin yang diberikan electrical stimulation (ES) terlebih dahulu lebih efektif daripada senam wajah dan electrical stimulation(ES) dalam meningkatkan kemampuan fungsional wajah facial palsy baik central facial palsy pada penelitian dari (Barathi et al., 2019) dengan perbedaan yang sangat signifikan $(p$-value $=0.038)$ maupun peripheral facial palsy dari penelitian (Bukhari et al., 2020) dengan $p$-value $=0.00$. Menurut teori sebelumnya, electrical stimulation dapat mempertahankan massa otot dan meningkatkan hasil fungsional pasien dengan meningkatkan restorasi aksonal (Goldie et al., 2016).

Pada subjek central facial palsy (lesi UMN dengan facial palsy unilateral), dibandingkan dengan intervensi lain, mirror therapy exercise dengan tablet PC dikombinasikan latihan orofasial memiliki perbedaan yang signifikan $\quad(p$-value $=0.04)$ dibandingkan dengan edukasi latihan orofasial saja berdasarkan penelitian (Kang et al., 2017).
Selain itu, mirror therapy exercise dengan kombinasi mirror imagery yang menggunakan perangkat lunak khusus juga memiliki perbedaan yang signifikan $(p$-value $=0.043)$ dibandingkan dengan latihan rehabilitasi tradisional seperti massage diri pada wajah dan leher; latihan pernapasan dan relaksasi; latihan untuk mengkoordinasikan kedua sisi dan mengurangi sinkinesis dan bibir sesuai dengan pendekatan myofascial untuk rehabilitasi; latihan huruf dan kata; dan latihan ekspresif berdasarkan penelitian (Paolucci et al., 2020).

Pada subjek peripheral facial palsy dengan bell's palsy akut atau berat (grade III-VI house brackmann scale) yang telah diberi obat-obatan, tidak ada perbedaan yang signifikan antara mirror therapy exercise dibandingkan dengan set biofeedback baik dari peningkatan kemampuan fungsional wajah ( $p$-value $=0.085)$ maupun kualitas hidup ( $p$ value $=0.07)$ pada penelitian (Eliyspoor C Baghban et al.,2017). Mirror therapy exercise yang dimodifikasi seperti mirror book therapy tidak memiliki perbedaan signifikan dalam meningkatkan kemampuan fungsional wajah dibandingkan dengan rehabilitasi standar (edukasi ulang neuromuskuler, massage, pelepasan myofascial, peregangan dan pelatihan postural). Begitupun Mirror Effect Plus Protocol (MEPP) menggunakan website gratis tidak lebih efektif dalam meningkatkan kemampuan fungsional wajah ( $\mathrm{p}$ value $=0.073$ ) dibandingkan dengan kelompok kontrol yang hanya diberikan edukasi. 


\section{PEMBAHASAN}

Mirror therapy exercise adalah intervensi terapeutik yang relatif baru dan terdiri dari senam wajah yang dilakukan secara aktif dengan tambahan input visual feedback. Saat melakukan senam wajah, penderita diminta untuk menatap pantulan di cermin atau layar dari perangkat lunak dan secara bersamaan membayangkan bahwa wajah mereka, terutama sisi yang lumpuh, adalah milik mereka sendiri dan dapat dikontrol selama tugas motorik. (Abidin et al., 2017; Ding et al., 2020)

Senam wajah dapat berupa ekspresi wajah terdiri dari lima gerakan (hidung keriput, cemberut, pipi meniup, kerutan dahi, dan senyum mulut terbuka) yang diulang masing-masing 10 kali. Pengucapannya termasuk mengatakan "/ A: /", "/ u: /", dan "/ z /" selama 3-5 detik, yang diulangi 10 kali. Selain itu, terdapat bentuk lain senam wajah yang dapat dilakukan yaitu mengangkat alis, meninggikan sudut bibir seperti mengucapkan "E" pipi, cemberut, menutup mata perlahan, menutup hanya satu mata secara bergantian, membuka mulut dan mengatakan "A", mengerucutkan bibir seperti mengucapkan "O", mengucapkan bergantian "E","A","O", tersenyum dengan dan tanpa menunjukkan gigi, pipi mengembang dengan bibir tertutup, bibir menekan, membaca dan berbicara dengan lantang. (Ding et al., 2020; Eliyspoor C Baghban et al., 2017)

Pada dasarnya, prinsip mirror therapy exercise yang telah didapatkan dari 7 literatur adalah serangkaian gerakan senam wajah menggunakan visual feedback berupa gambar/pantulan wajah sisi yang tidak terpengaruh untuk kemudian diperhatikan dan diikuti gerakannya terhadap sisi yang terpengaruh. Yang membedakan intervensi mirror therapy exercise dengan intervensi rehabilitasi lainnya adalah pada masukan input sensory visual yang dapat memengaruhi tingkat perbaikan cedera saraf.

Aktivitas fisik mengubah massa dan tonus otot, fungsi kardiovaskular, serta otak, sedangkan visual feedback pada mirror therapy exercise akan merangsang emosi berupa motivasi karena penderita facial palsy dapat melihat bagian sisi wajah yang tidak terpengaruh bergerak normal, hal tersebut memudahkan terjadinya re-learning motoric otak penderita central facial palsy, yang mana disebut dengan teori neuroplastisitas. (Barth et al., 2020; Demarin et al., 2014)

Neuroplastisitas adalah kemampuan otak untuk membentuk koneksi saraf baru sebagai respons terhadap situasi baru atau perubahan lingkungan. Pembelajaran motorik ditingkatkan selama aktivasi sistem neuron cermin, dengan cara mengakseswilayah otak dan meningkatkan penerimaan sarafmenggunakan berbagai teknik peningkatan sensorik. (Demarin et al., 2014)

Mirror visual feedback (MVF)

pada mirror therapy exercise dianggap mengaktifkan sistem neuron cermin dengan cara yang serupa. MVF meningkatkan citra motorik melalui simulasi internal gerakan sehingga dapat mengaktifkan sirkuit saraf yang berperan dalam kontrol motorik. (Deconinck et al., 2015).

Dalam studi sebelumnya didapatkan bahwa dalam 
pembelajaran sistem sensorik, emosi yang terkait dengan masukan sensorik seperti penglihatan (visual) dapat lebih meningkatkan penerimaan ke daerah motorik (Masterson, 2015). Mekanisme cermin juga ada di insula dan rostral cingulate, yaitu mengubah situasi emosional yang diamati menjadi respons motorik viskositas yang serupa dengan yang ada ketika seseorang benarbenar mengalami emosi tersebut (Chen et al., 2017).

Pada peripheral facial palsy, apabila terjadi cedera saraf perifer maka akan terjadi rangkaian proses yang kompleks dan teratur untuk membuang jaringan yang rusak dan memulai proses perbaikan. Tingkat regenerasi dapat tergantung dari beratnya cedera saraf, waktu terjadinya invervasi dan kondisi jaringan saraf perifer sendiri. (Dewi et al., 2014)

Sistem saraf perifer dan pusat terintegrasi secara fungsional mengenai konsekuensi cedera saraf: lesi saraf perifer selalu menghasilkan modifikasi dan reorganisasi sentral yang mendalam dan bertahan lama. Mekanisme plastisitas dan reorganisasi sirkuit tulang belakang dan otak yang terkait dengan neuron perifer yang diakotomi adalah kompleks; yaitu dapat mengakibatkan perubahan fungsional adaptif yang menguntungkan atau sebaliknya menyebabkan perubahan maladaptif yang memperburuk prognosis. Penelitian sebelumnya telah mempelajari bahwa memanipulasi aliran input sensorik atau output motorik yang diinduksi oleh pelatihan/pembelajaran melalui studi plastisitas dapat menurunan risiko perubahan maladaptif dari perbaikan saraf perifer (Mohanty et al., 2015), hal ini dapat dilakukan dengan mirror therapy exercise.

Penelitian ini terbatas karena menggunakan literatur eksperimen yang diterbitkan 10 tahun terakhir dan dapat diakses secara gratis.

\section{KESIMPULAN}

Berdasarkan hasil kajian literatur yang dilakukan, maka peneliti menyimpulkan bahwa mirror therapy exercise berpengaruh dalam meningkatkan kemampuan fungsional wajah penderita facial palsy. Mirror therapy exercise, mirror book therapy dan Mirror Effect Plus Protocol (MEPP) tidak memiliki perbedaan signifikan dalam meningkatkan kemampuan fungsional wajah dibandingkan dengan rehabilitasi standard (edukasi ulang neuromuskuler, massage, pelepasan myofascial, peregangan dan pelatihan postural) dan set biofeedback. Untuk mencapai tingkat efektivitas yang lebih signifikan dibandingkan dengan intervensi lain, mirror therapy exercise menggunakan cermin maupun tablet PC dapat dilakukan dengan kombinasi intervensi lainnya seperti electrical stimulation (ES), latihan orofasial, dan mirror imagery dengan perangkat lunak.

Penelitian dimasa depan disarankan untuk mengetahui dan mengevaluasi dosis yang akurat berdasarkan jenis dan tingkat keparahan facial palsy. Selain itu, diperlukan kajian lebih lanjut mengenai efektivitas mirror therapy execise untuk penderita facial palsy yang terdeteksi COVID-19 dengan tujuan memberikan pelayanan sesuai 
dengan pedoman dan kode etik fisioterapi yang memenuhi standar pelayanan sebagai tenaga kesehatan.

\section{DAFTAR PUSTAKA}

Abidin, Z., . K., \& Haryanto, D. (2017). Pengaruh Infra Red, Massage dan Mirror Exercise pada Bell's Palsy. Jurnal Fisioterapi Dan Rehabilitasi, 1(2), $18-25$. https://doi.org/10.33660/jfrw hs.v1i2.56

Akina Tamaki, MD Claudia I. Cabrera, MD, MS Shawn Li, MD Cyrus Rabbani, MD Jason E. Thuener, MD Rod P. Rezaee, MD Nicole Fowler, M. (2021). Incidence of Bell Palsy in Patients With COVID-19. JAMA Otolaryngology-Head\&Neck Surgery, 147(Number 8), 767. https://doi.org/10.1056/nejmo a2034577

Barth, J. M., Stezar, G. L., Acierno, G. C., Kim, T. J., \& Reilly, M. J. (2020). Mirror Book Therapy for the treatment of Idiopathic Facial Palsy. Ear, Nose and Throat Journal, 93(9), $0-4$. https://doi.org/10.1177/01455 61320913211

Bharathi, K., Ramya, S., \& Malarvizhi, P. D. (2019). The Efficacy of Mirror Therapy in Facial Palsy among Subjects with Facial Paralysis. International Journal of Research and Scientific Innovation (IJRSI) |, VI(IX), 9-13.

https;//www.rsisinternational. org

Bukhari, S., Majeed, S., Noor, S., \& Khan, S. (2020). Effects of mirror therapy on Bells palsy. Journal of Riphah College of Rehabilitation Sciences, 8(1), 37.

https://doi.org/10.5455/jrcrs.20 20080108

Chang, Y. S., Choi, J. E., Kim, S. W., Baek, S. Y., \& Cho, Y. S. (2016). Prevalence and associated factors of facial palsy and lifestyle characteristics: Data from the Korean National Health and Nutrition Examination Survey 20102012. BMJ Open, 6(11), 1-7. https://doi.org/10.1136/bmjope n-2016-012628

Chen, W., Yuan, T., Wang, Y., \& Ding, J. (2017). Human mirror neuron system and its plasticity. Neural Regeneration Research, 3(3, March 2008), 321-323.

Codeluppi, L., Venturelli, F., Rossi, J., Fasano, A., Pacillo, F., Cavallieri, F., Giorgi Rossi, P., \& Valzania, F. (2020). Facial palsy during the COVID-19 pandemic. Brain and Behavior, August, 1-5. https://doi.org/10.1002/brb3.19 39

Deconinck, F. J. A., Smorenburg, A. R. P., Benham, A., Ledebt, A., Feltham, M. G., \& Savelsbergh, G. J. P. (2015). Reflections on mirror therapy: A systematic review of the effect of mirror visual feedback on the brain. Neurorehabilitation and Neural Repair, 29(4), 349-361. https://doi.org/10.1177/154596 8314546134

Dewi, A. C., Kurniawan, S. N., Husna, M., \& Rahayu, M. (2014). Regenerasi saraf perifer. In Neurona (Vol. 32, Issue 1)

Demarin, V., Morović, S., \& Béné, R. (2014). 
Periodicum Biologorum, 116(2), 209-211. https://hrcak.srce.hr/126369

Ding, L., Li, L., Xu, Z., Tian, J., Chen, S., Wang, H., Yang, M., Cui, X., Cao, L., \& Jia, J. (2020). Computer vision technology-based face mirroring system providing mirror therapy for Bell's palsy patients. Disability and Rehabilitation, 42(6), 833840.

https://doi.org/10.1080/09638 288.2018.1510551

Egilmez, O. K. (2021). Can COVID-19 Cause Peripheral Facial Nerve Palsy?. SN Comprehensive Clinical Medicine, 12-14. https://doi.org/https://doi.org/ 10.1007/s42399-021-00967-4

Eliyspoor C Baghban, D., Akbarzadeh, A., Oshnari, L. A., Mirzakhani, N., Parsamanesh, T., Kamalifar, M., \& Javantash, A. (2017). The Comparison between Exercise Therapy and Biofeedback Therapy in Facial Function and Quality Of Life of Bell's palsy. JCPR Journal of Clinical Physiotherapy Research Original Article Journal of Clinical Physiotherapy Research, 2(3), 139-143. http://journals.sbmu.ac.ir/phy siotherapy/

Goldie, S., Sandeman, J., Cole, R., Dennis, S., \& Swain, I. (2016). Electrical stimulation treatment for facial palsy after revision pleomorphic adenoma surgery. Journal of Surgical Case Reports, 2016(4), rjw057. https://doi.org/10.1093/jscr/rj w057

Hassan, A., Mustafa, K., \& Suleiman, A. M. (2020). Bell' s Palsy: A Prospective Study. International Journal of Dentistry, 2020, 1-5. https://doi.org/https://doi.org/10 $.1155 / 2020 / 2160256$

Jason C. Nellis, M., Masaru Ishii, MD, P., Patrick J. Byrne, MD, M., Kofi D. O. Boahene, M., Jacob K. Dey, M., \& Lisa E. Ishii, M. (2017). Association Among Facial Paralysis, Depression, and Quality of Life in Facial Plastic Surgery Patients Jason. JAMA Facial Plastic Surgery, 19(3), 190196.

https://doi.org/10.1001/jamafac ial.2016.1462.

Kang, J. A., Chun, M. H., Choi, S. J., Chang, M. C., \& Yi, Y. G. (2017). Effects of mirror therapy using a tablet PC on central facial paresis in stroke patients. Annals of Rehabilitation Medicine, 41(3), 347-353.

https://doi.org/10.5535/arm.201 7.41.3.347

Martineau, S., Rahal, A., Piette, É., Chouinard, A. M., \& Marcotte, K. (2020). The Mirror Effect Plus Protocol for acute Bell's palsy: a randomised and longitudinal study on facial rehabilitation. Acta OtoLaryngologica, $\quad 0(0), \quad 1-6$. https://doi.org/10.1080/000164 89.2020.1842905

Masterson, J. (2015). The Role of Emotion, Vision and Touch in Movement Learning Neuroplasticity and the Mirror Neuron System. Journal of Psychology and Clinical Psychiatry, 3(5), 1-9. 
https://doi.org/10.15406/jpcp y.2015.03.00149

Moch, B. (2017). Bell's Palsy (BP). Saintika Medika, 7(2), 20-25. https://doi.org/10.22219/sm.v $7 \mathrm{i} 2.4073$

Mohanty, C. B., Bhat, D., \& Indira Devi, B. (2015). Role of central plasticity in the outcome of peripheral nerve regeneration. Neurosurgery, 77(3), 418-423. https://doi.org/10.1227/NEU. 0000000000000851

Oke, I. O., Oladunjoye, O. O., Oladunjoye, A. O., Paudel, A., \& Zimmerman, R. (2021). Bell's Palsy as a Late Neurologic Manifestation of COVID-19 Infection. Cureus, 13(3), 13-16. https://doi.org/10.7759/cureus .13881

Paolucci, T., Cardarola, A., Colonnelli, P., Ferracuti, G., Gonnella, R., Murgia, M., Santilli, V., Paoloni, M., Bernetti, A., Agostini, F., \& Mangone, M. (2020). Give me a kiss!: An integrative rehabilitative training program with motor imagery and mirror therapy for recovery of facial palsy. European Journal of Physical and Rehabilitation Medicine, 56(1), 58-67. https://doi.org/10.23736/S197 3-9087.19.05757-5

Rowhani-Rahbar, A., Baxter, R., Rasgon, B., Ray, P., Black, S., Klein, J. O., \& Klein, N. P. (2012). Epidemiologic and clinical features of Bell's palsy among children in Northern California. Neuroepidemiology, 38(4), 252-258. https://doi.org/10.1159/000338 303

Vaughan, A., Gardner, D., Miles, A., Copley, A., Wenke, R., \& Coulson, S. (2020). A systematic review of physical rehabilitation of facial palsy. Frontiers in Neurology, 11(March). https://doi.org/10.3389/fneur.20 20.00222 